\title{
INTERFACIAL DEBONDING OF ICE-ASPHALT CONCRETE
}

\author{
Ei-ichi TAZAWA*, Yuji MIZO-U-E** \\ and Takeo KOJIMA***
}

\begin{abstract}
In order to clarify the nature of the bonding mechanism between ice and asphalt concrete and to develope new techniques to reduce debonding resistance, a series of experimental investigation was conducted. Surface energy was varied by using various water repellents, and stiffness of asphalt concrete was varied by mixing crushed rubber particles with the asphalt. Correlations between these variables were investigated and the following conclusion was obtained. Reducing surface energy and/ or increasing deformability of the asphalt concrete is an effective way to decrease interfacial bonding between ice and asphalt concrete. In this regard, use of water repellents or replacement of aggregate with rubber particles is a promising method to facilitate debonding of ice and asphalt concrete.
\end{abstract}

Keywords : debonding, interface, ice, asphalt, repellent

\section{INTRODUCTION}

In order to clarify bonding mechanism between ice and asphalt concrete and to develop new debonding technique, series of experimental investigations were conducted. Results of these investigation will provide useful informations on developing a new type of asphalt concrete or designing a new mechanism for ice removal máchine.

Interfacial debonding resistance were measured by three different methods. One is single plane shear test which is originally contrived for soil test, the second is pure tension test in which tensile stress field is generated at the interface as a reflected wave induced by impact of drop hammer, and the third method is local compression test prosecuted under static or dynamic condition. In the second test, number of repeated cycle until debonding was measured and total enegy spent for debonding was taken as a measure. Surface energy and surface roughness of asphalt concrete were measured by roughness tester and contact angle tester provided with optical microscope respectively. Various materials, which might change the debonding characteristics in a surface chemical or mechanical manner, were incorporated with asphalt concrete. As the former method, various types of water repellent agent were coated on asphalt concrete surface by brush-painting or mixed with asphalt. As the latter method, partial 'replacemet of aggregate with rubber particles was adopted.

\footnotetext{
* Professor at Hiroshima University

(4-1, kagamiyama 1-chome Higashihiroshima Japan)

** A graduate student at Hiroshima University

*** Chemical engineer working for Hitachi Chemical Co., LTD
}

Table 1 Marshall Test

\begin{tabular}{|l|c|}
\hline Asphalt content $(\%)$ & 6.2 \\
\hline Porosity $(\%)$ & 3.7 \\
\hline Degree of saturation $(\%)$ & 79.4 \\
\hline Density $\left(\mathrm{g} / \mathrm{cm}^{3}\right)$ & 2.373 \\
\hline Flow $(\mathrm{cm})$ & 3.1 \\
\hline Stability $(\mathrm{kg})$ & 900 \\
\hline
\end{tabular}

In order to clarify the debonding characteristics of ice, influences of these variables were experimentally studied and effective methods to facilitate debonding of ice-asphalt concrete interface were investigated.

\section{EXPERIMENTAL PROCEDURES}

\section{(1) Materials used for series 1}

a) Asphalt concrete

Two types of asphalt plate were prepared. One was asphalt concrete that was mixed with quite popular mix proportion using straight asphalt $60 / 80$ (penetration : 69 , softening point : $49.0^{\circ} \mathrm{C}$ ).

Results of Marshall test of this mix is shown in Table 1. The other is mortar plate that contains no coarse aggregate.

b) $\mathrm{BL}$ asphalt emulsion

Properties of $\mathrm{BL}$ asphalt emulsion used for flattening the specimen surface is shown in Table 2. Nonionic surfactant of higher alcohol ether was used as emulsifier. Toyoura silica sand prescribed in Japanese standard and normal Portland cement were also used for flattening treatment.

c) Water repellent agents

In order to reduce surface tension of asphalt concrete, various materials shown in Table 3. were selected from commercial products. One of these 
Table 2 Properties of BL Emulsion

\begin{tabular}{|c|c|c|c|}
\hline \multicolumn{3}{|c|}{ Engler degree $\left(25^{\circ} \mathrm{C}\right)$} & $5 \sim 15$ \\
\hline \multicolumn{2}{|c|}{ Plus sieve $(1190 \mu \mathrm{m})$} & $\%$ & $<0.3$ \\
\hline \multirow{4}{*}{ 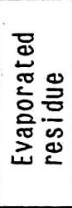 } & Residue & $\%$ & $>57$ \\
\hline & Penetration $\left(25^{\circ} \mathrm{C}\right)$ & & 60 \\
\hline & Ductility $\left(15^{\circ} \mathrm{C}\right)$ & & $>100$ \\
\hline & $\begin{array}{l}\text { Solubility in } \\
\text { trichloro-ethane }\end{array}$ & \% & 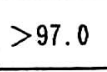 \\
\hline
\end{tabular}

Table 3 Water Repellent Agent

\begin{tabular}{|c|c|}
\hline $\begin{array}{l}1 \\
2 \\
3 \\
4 \\
5\end{array}$ & $\begin{array}{l}\text { organic polysiloxane bonded with special metal } \\
\text { dimethyl polysiloxane } \\
\text { denatured polysiloxane } \\
\text { silicone water repellent agent (polysiloxane group) } \\
\text { silicone water repellent agent (polysiloxane group) }\end{array}$ \\
\hline 6 & silane $\left(\mathrm{Si}, \mathrm{H}_{2 n+2}\right)$ \\
\hline $\begin{array}{l}7 \\
8\end{array}$ & $\begin{array}{l}\text { fluorine contained resin (solvent:xylene) } \\
\text { fluorine contained resin (solvent:acetone/ethyl acetate 50/50) }\end{array}$ \\
\hline $\begin{array}{r}9 \\
10 \\
11\end{array}$ & $\begin{array}{l}\text { oleic acid } \\
\text { surface active agent of nonionic type (sorbitan ester) } \\
\text { nixture of higher fatty acid, zinc naphthenate, polyvinyl resin } \\
\text { ester, penetration promotor, solvent and diluent }\end{array}$ \\
\hline $\begin{array}{l}12 \\
13\end{array}$ & $\begin{array}{l}\text { pulverized silicone polyper (powder) } \\
\text { treated hydropholic silica powder }\end{array}$ \\
\hline
\end{tabular}

materials was applied on surface of asphalt concrete or mixed with asphalt.

\section{d) Aggregate}

Crushed pelitic hornfels was used as coarse aggregate by blending two different sizes (No.6 and No. 7 by Japanese Standard). Sea sand was used as fine aggregate. Lime stone powder and screenings were also used. Same types of aggregate were used for series 2 except that screenings was not used for series 2 .

\section{(2) Materials used for series 2}

\section{a) Rubber tips}

Rubber particles manufactured by cryogenic pulverization of waste tires were classified into four different grain sizes, namely $5 \sim 3 \mathrm{~mm}, 3 \sim 1 \mathrm{~mm}, 1$ $\sim 0 \mathrm{~mm}$ and $0.6 \sim 0 \mathrm{~mm}$. Three types of rubber aggregate, that is, $5 \sim 3 \mathrm{~mm}, 0.6 \sim 0 \mathrm{~mm}$ and blended type were used. In the last rubber aggregate, equal amounts of the four different sizes were blended.

\section{b) Asphalt}

Straight asphalt 60/80 (penetration : 66 , softening point : $48^{\circ} \mathrm{C}$, ductility : $>150 \mathrm{~cm}$ ) was used. (3) Methods of experiments for series 1

a) Surface roughness of asphalt concrete

Roughness tester shown in Photo 1 was used to record the magnified profile of asphalt concrete surface. Tracing of the surface was made by ball type of stylus. As a roughness index, average

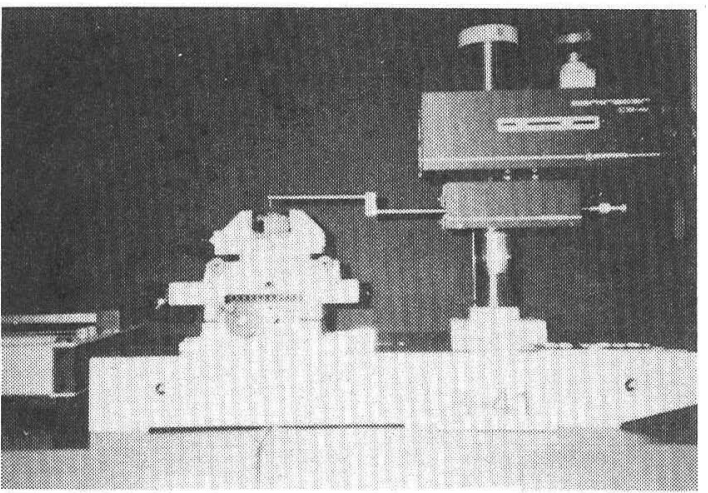

Photo 1 Roughness Tester

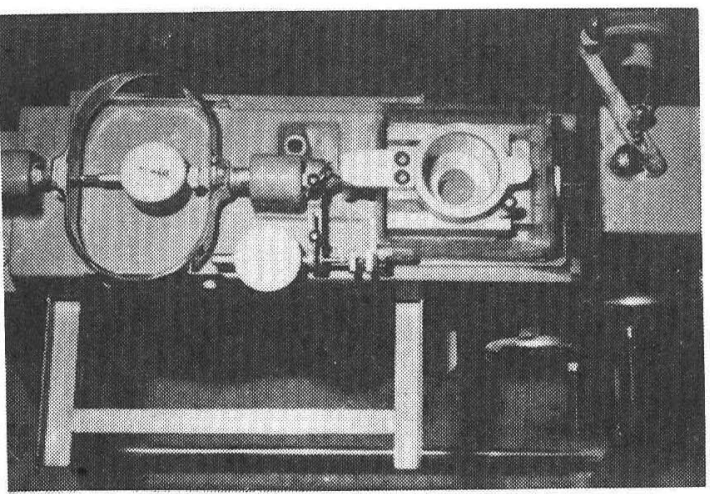

Photo 2 Single Plane Shear Apparatus

deviation from center line $(R a)$ defined by equation-(1) for measurement length $L$ was used, where $x$ is distance along the center line and $y$ is deviation from center line in micrometer. In this study $L$ was $16 \mathrm{~mm}$.

$$
R a=\frac{1}{L} \int_{0}^{L}|y(x)| d x
$$

b) Debonding strength by single plane shear

Single plane shear tester that is originally contrived for soil test (Photo 2) was used. Shear plane was carefully adjusted so that the ice-asphalt concrete interface concides with the plane. Applied load and shear displacement was measured by proving ring and dial gauge $(1 / 1000 \mathrm{~mm}$ scale) respectively. Thickness of ice and asphalt concrete was $13.5 \mathrm{~mm}$ respectively and ice was prepared by placing a specimen overnight in a refrigerator.

c) Debonding strength by impact tension

As is shown in Fig.1, tensile stress wave is generated at the ice-asphalt concrete interface by impact of drop hammer (Fig.2). Weight of $1 \mathrm{~kg}$ was freely dropped from different heights. Specimen, $60 \mathrm{~mm}$ in diameter, was screwed to the downmost end of the apparatus. Number of repeated cycles of drop up to debonding was measured. 


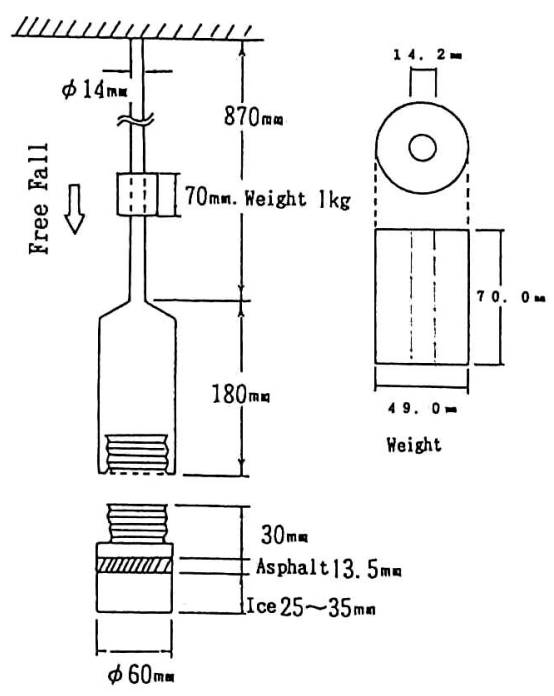

Fig.1 Impact Tension Test

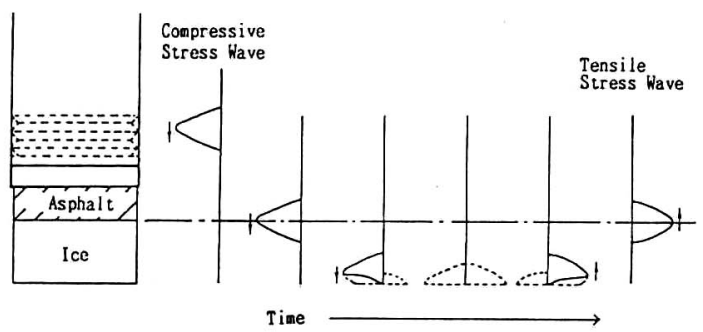

Fig.2 Principle of Impact Tensile Stress Generation

d) Contact angle and surface tension

Contact angle was measured by sessile drop method using contact angle tester provided with microscope (Photo 3). Surface tension was measured by capillary rise using $0.0408 \mathrm{~cm}$ tube. Correction for meniscus was made in accordence with Rayleigh's equation. Contamination of inner surface of tube was eliminated by sodium dichromate solution and the result was checked by comparing two measurements taken for opposite wetting direction.

e) Debonding test by impact blow

Impact energy of $\mathrm{N}$ type Schmidt Hammer (impact energy : $0.255 \mathrm{kgf} \cdot \mathrm{m}$ ) was applied on thin layer of ice bonded to asphalt concrete. Failure aspect was visually observed.

(4) Methods of experiments for series 2

a) Uni-axial compression test of asphalt concrete

Cylindrical specimen $60 \mathrm{~mm}$ in diameter was cut from $30 \times 30 \times 5 \mathrm{~cm}$ asphalt concrete plate and both ends were finished by gypsum capping. Compressive load was applied by constant crosshead speed 1 $\mathrm{mm} / \mathrm{min}$ and stress-strain curve was obtained. Test temperature was $20^{\circ} \mathrm{C}$ and $-15^{\circ} \mathrm{C}$.

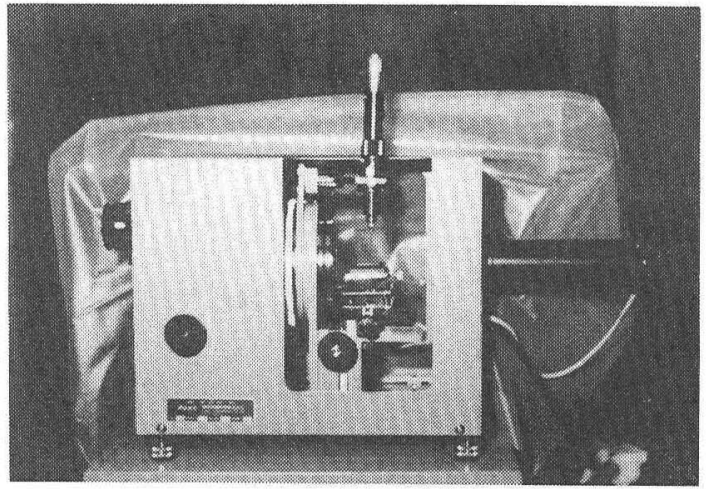

Photo 3 Contact Angle Tester

Table 4 Roughness of Asphalt Concrete

\begin{tabular}{|c|c|c|c|}
\hline $\begin{array}{c}\text { Specimen } \\
\text { Number }\end{array}$ & $\begin{array}{c}\text { Average deviation } \\
\text { from center line } \\
\text { R a }\end{array}$ & $\begin{array}{c}\text { Maximum height } \\
\text { R m a x }\end{array}$ & $\begin{array}{c}\text { Average roughness } \\
\text { from ten sumnits } \\
\text { R z }\end{array}$ \\
\hline i & 42.6 & 503.5 & 295.8 \\
ii & 27.8 & 396.9 & 163.6 \\
iii & 24.9 & 307.5 & 142.4 \\
iv & 22.7 & 252.2 & 119.0 \\
v & 10.1 & 162.7 & 45.0 \\
vi & 5.0 & 56.7 & 31.2 \\
\hline
\end{tabular}

(measurement length $=16.0 \mathrm{~mm}$, unit: $\mu \mathrm{m}$ )

b) Uni-axial compression test of ice-bonded asphalt concrete

Seventy $\mathrm{ml}$ of deionized water was poured on top of cylindrical asphalt concrete specimen $(\phi 100.0$ $\mathrm{mm} \times 63.5 \mathrm{~mm}$ ) and was frozen at $-10^{\circ} \mathrm{C}$. Local compressive load was statically applied at $-15^{\circ} \mathrm{C}$. Diameter of pressing plunger was $35 \mathrm{~mm}$ and crosshead speed was $2 \mathrm{~mm} / \mathrm{min}$. Mix proportion of asphalt concrete was optimized in advance for each type of rubber aggregate by Marshall test and porosity measurement. In addition to stress-strain curve, the failure load of bonded ice was measured.

\section{(5) Factors varied}

a) Series 1

Four types of asphalt concrete surface were studied.

a) Asphalt concrete surface

b) Asphalt mortar surface

c) Finished surface of asphalt concrete

d) Cut surface of asphalt concrete

No coarse aggregate was used to get b) surface, for c) surface asphalt concrete was finished with BL asphalt emulsion containing silica sand and cement (weight ratio $1: 2: 1$ ) and asphalt concrete was cut by diamond cutter to get d) surface. In order to control roughness of pavement, a) surface and d) surface described above were polished by sand paper in different degree, and six steps of roughness shown in Table 4 were obtained, where rank i ) to iv) were obatined from surface a) and 


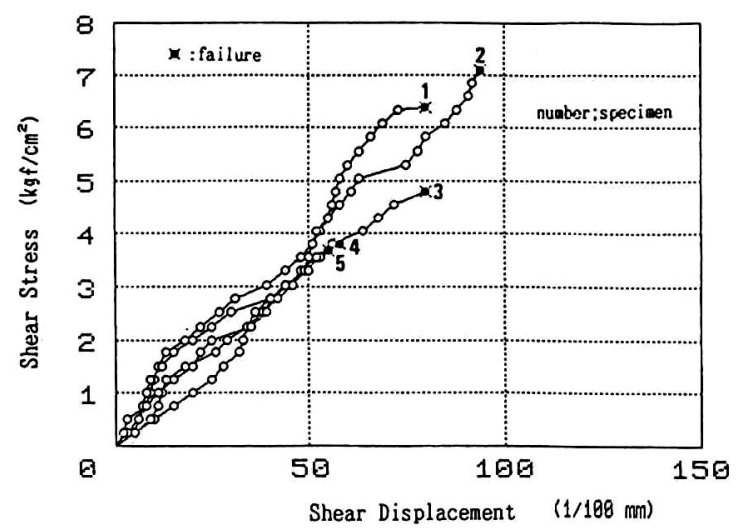

Fig.3 Single Plane Shear Test of Ice $\left(-20^{\circ} \mathrm{C}\right)$

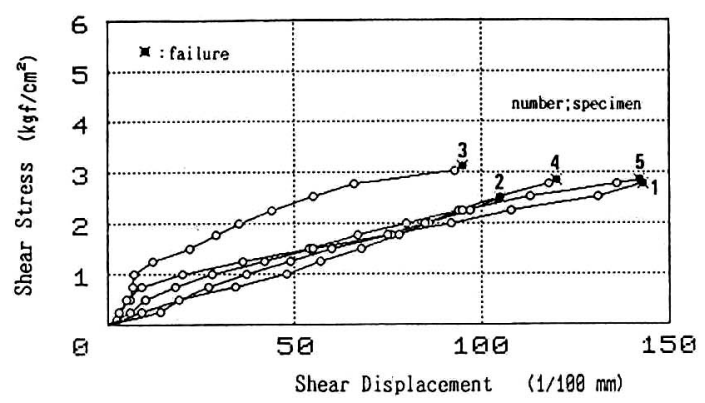

Fig.4 Single Plane Shear Test of Compressed Artificial Snow $\left(-20^{\circ} \mathrm{C}\right)$

rank v ) and vi) from surface d). Rank i ) corresponds to original asphalt concrete surface just after finished. For every type of surface, liquid type water repellent agents listed in Table 3 were coated, and some types of agents were mixed with asphalt. Single plane shear test was carried out for all surfaces bonded with ice or compressed artificial snow $(\rho=0.8)$ and impact tension test was carried out for the specimens with different surface roughness. Normally, tests were done at temperatures $-12.5,-15.0$ and $-17.5^{\circ} \mathrm{C}$, but some tests were done at $-10^{\circ} \mathrm{C}$ and $-20^{\circ} \mathrm{C}$.

Artificial snow was prepared by compressing crashed ice particles in a steel pipe $60 \mathrm{~mm}$ in diameter until its bulk specific gravity becomes 0.8 .

\section{TEST RESULTS OF SERIES 1}

(1) Single plane shear test of ice and compressed artificial snow

Shear stress and shear displacement curves for both cases are shown in Fig.3, and 4. More or less linear relationship was obtained. The slope of the latter was approximately one third of the former. Average shear strength of ice was $5.0 \mathrm{kgf} / \mathrm{cm}^{2}$ and that of compressed artificial snow was $2.8 \mathrm{kgf} / \mathrm{cm}^{2}$.

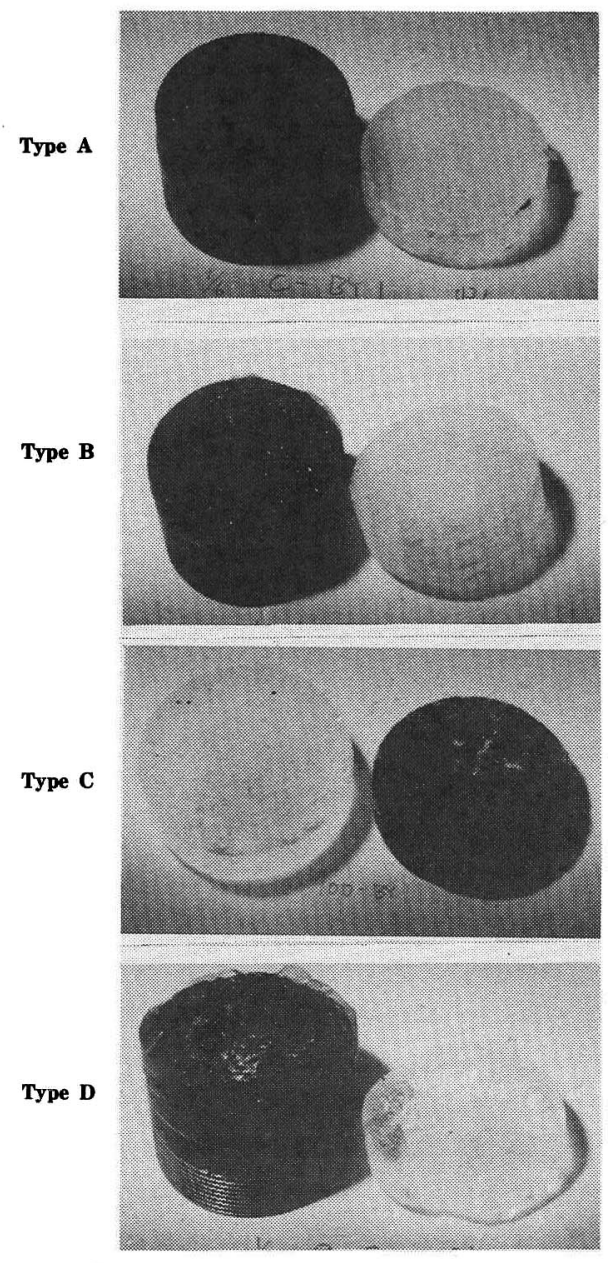

Photo 4 Types of Failure Surface

(2) Type of failure of ice bonded asphalt concrete

Failure could be classified into four groups. (photo 4)

Type A : complete debonding at ice-asphalt interface

Type B : interfacial debonding with local failure of ice at indent spots

Type $C$ : some area failed in ice and the other area failed like type A or B

Type D : failure of ice (Ice in this list means ice or compressed artificial snow.)

(3) Shear debonding test of ice-asphalt concrete interface

Influence of types of pavement and roughness of asphalt concrete are shown in Fig.5, and 6 for untreated surface. Shear strength and shear displacement of interface were smaller than those of ice or compressed artificial snow. Effect of water repellent coating (No.3 agent) is shown in Fig.7 for different roughness of pavement. Water repellent 


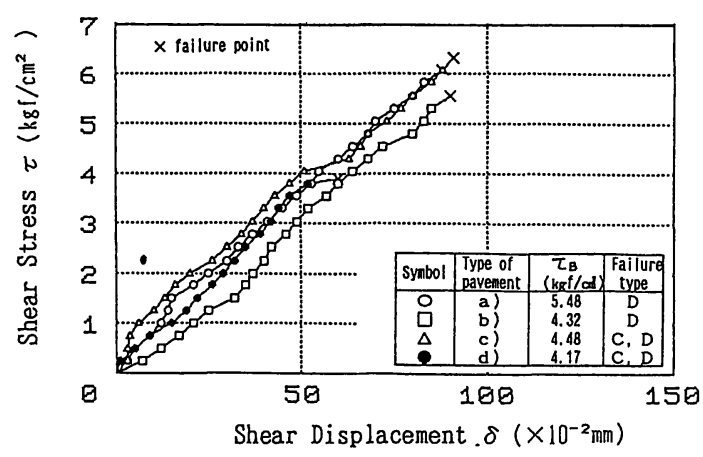

Fig.5 Single Plane Shear Test of Ice-asphalt concrete Interface

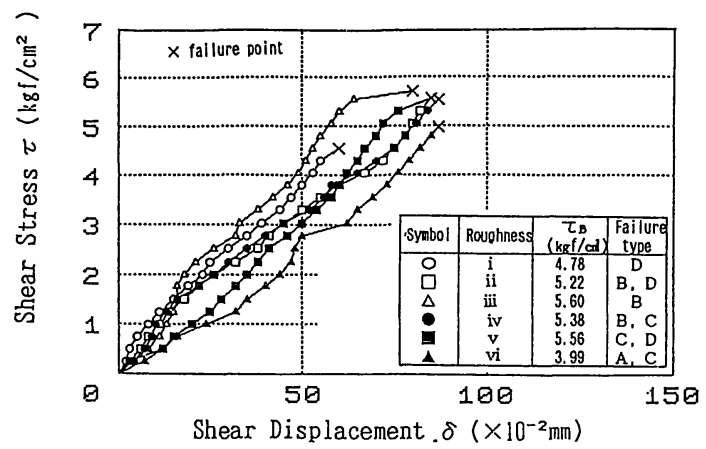

Fig.6 Single Plane Shear Test of Ice-asphalt concrete Interface

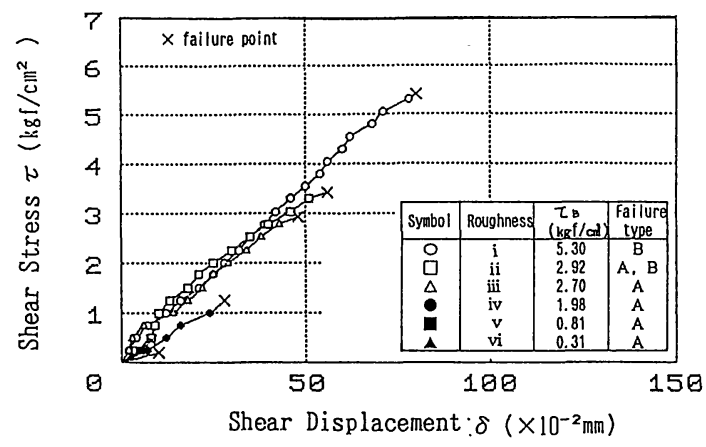

Fig.7 Single Plane Shear Test of Ice-Treated asphalt concrete Interface (No.3)

agent can reduce the shear strength of interface more effectively for smooth surface than for rough surface.

\section{(4) Impact tension test of ice-asphalt concrete interface}

Typical results are shown in Fig.8 and Table 5. Roughness of pavement exhibits great influence on debonding energy of treated and untreated interface. It is clear that water repellent agent is very effective. Type of failure for repellent coated surface was only type A for all test cases.
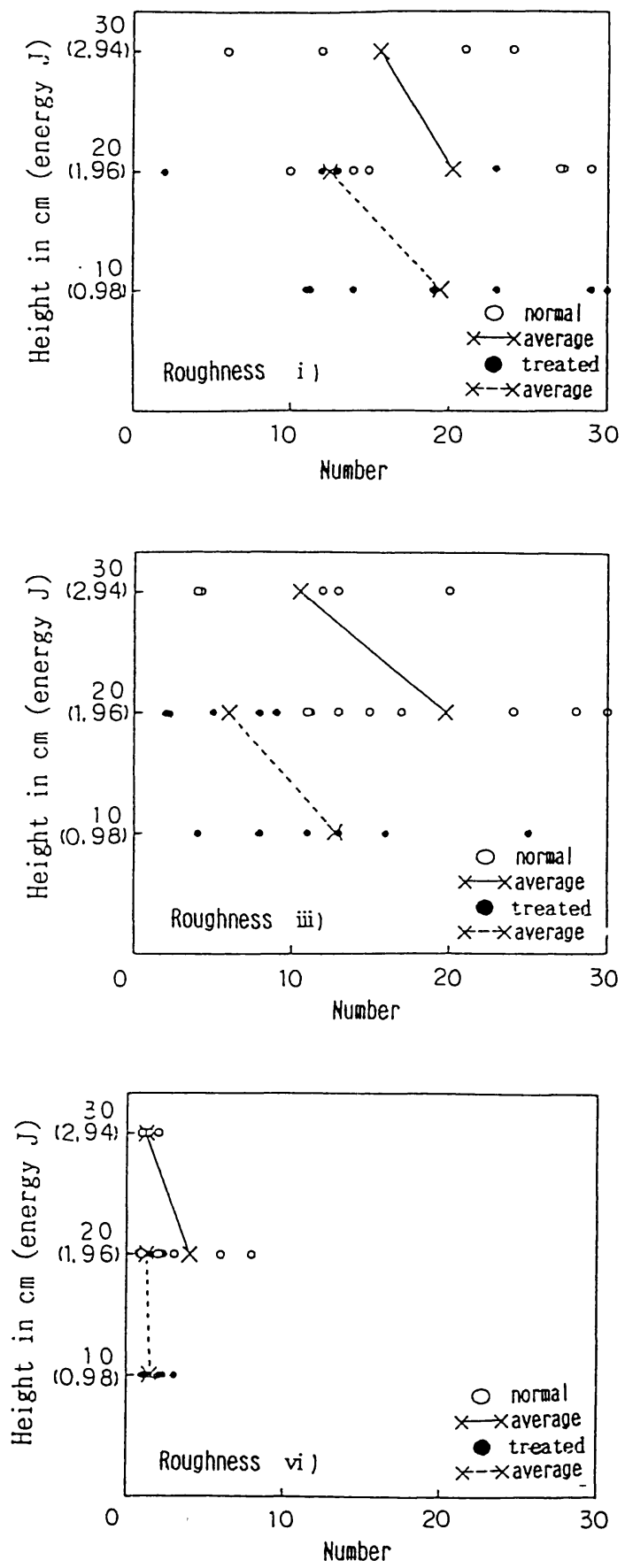

Fig.8 Results of Impact Tension Test $\left(-15^{\circ} \mathrm{C}\right)$

\section{(5) Adhesional energy of water-saphalt inter- face}

Adhesional energy $W_{a}$ should be corrected by the amount of $\pi_{c}$ that is reduction in free energy due to adsorption of saturated vapour of liquid. Adhesional energy obtained by sessile drop method corresponding to $W_{a}-\pi_{c}$ is shown in 
Table 5 Result of Impact Tension Test

\begin{tabular}{|c|c|c|c|c|c|c|}
\hline Type & Roughness & $\begin{array}{l}\text { Orop } \\
\text { Height } \\
\text { (ca) }\end{array}$ & $\begin{array}{l}\text { Average } \\
\text { Number } \\
\text { of Drop }\end{array}$ & $\begin{array}{l}\text { Standard } \\
\text { Deviation } \\
\text { of Drop } \\
\text { Number }\end{array}$ & $\begin{array}{l}\text { Required } \\
\text { Energy } \\
\text { (J) }\end{array}$ & $\begin{array}{l}\text { Probability } \\
\text { of Type A } \\
\text { (x) }\end{array}$ \\
\hline \multirow{12}{*}{ 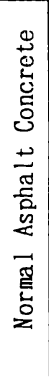 } & \multirow{2}{*}{ i } & 30 & 15.7 & 7.15 & 46.31 & 0 \\
\hline & & 20 & 20.3 & 7.52 & 39.85 & 0 \\
\hline & \multirow{2}{*}{ ii } & 30 & 11.3 & 6.38 & 33.08 & 0 \\
\hline & & 20 & 18.6 & 7.50 & 36.40 & 0 \\
\hline & \multirow{2}{*}{ ịi } & 30 & 10.6 & 6.05 & 31.16 & 0 \\
\hline & & 20 & 19.7 & 7.00 & 38.63 & 0 \\
\hline & \multirow{2}{*}{ iv } & 30 & 2.6 & 2.33 & 7.64 & 80 \\
\hline & & 20 & 6.8 & 2.40 & 13.33 & 40 \\
\hline & \multirow{2}{*}{$\mathrm{v}$} & 30 & 1.3 & 0.43 & 3.68 & 75 \\
\hline & & 20 & 5.8 & 4. 26 & 11.37 & 60 \\
\hline & \multirow{2}{*}{ vi } & 30 & 1.3 & 0.43 & 3.68 & 100 \\
\hline & & 20 & 4.0 & 2.61 & 7.84 & 100 \\
\hline \multirow{4}{*}{ 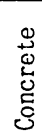 } & \multirow{2}{*}{ i } & 20 & 12.5 & 7.43 & 24.50 & 100 \\
\hline & & 10 & 19.6 & 7.44 & 19.18 & 100 \\
\hline & \multirow{2}{*}{ ii } & 20 & 8.8 & 5.01 & 17.31 & 100 \\
\hline & & 10 & 18.7 & 9.41 & 18.30 & 100 \\
\hline+ & \multirow{2}{*}{ iii } & 20 & 6.2 & 3.44 & 12.09 & 100 \\
\hline$\vec{\Xi}$ & & 10 & 12.8 & 6.62 & 12.57 & 100 \\
\hline â & \multirow{2}{*}{ iv } & 20 & 3.3 & 2.49 & 6.53 & 100 \\
\hline$<$ & & 10 & 9.0 & 5.55 & 8.82 & 100 \\
\hline$\Phi$ & \multirow[b]{2}{*}{$\mathrm{v}$} & 20 & 2.2 & 1.46 & 4.25 & 100 \\
\hline $\mathbb{E}$ & & 10 & 3.0 & 1.63 & 2.94 & 100 \\
\hline$\rightleftarrows$ & \multirow{2}{*}{ vi } & 20 & 1.3 & 0.47 & 2.61 & 100 \\
\hline & & 10 & 1.7 & 0.74 & 1.64 & 100 \\
\hline
\end{tabular}

Table 6 Contact Angle and $W_{a}-\pi_{c}$

\begin{tabular}{|c|c|c|c|c|}
\hline \multirow[b]{2}{*}{ Type of agent } & \multicolumn{2}{|c|}{ Glass } & \multicolumn{2}{|c|}{ Asphalt Concrete } \\
\hline & $\begin{array}{c}\text { Contact Angle } \\
\text { (degree) }\end{array}$ & $\begin{array}{l}\mathrm{w}_{\mathrm{a}}-\pi \\
(\mathrm{e} \mathrm{rg} / \mathrm{ad})\end{array}$ & $\begin{array}{c}\text { Contact Angle } \\
\text { (degree) }\end{array}$ & $\begin{array}{l}\mathrm{w}_{\mathrm{a}}-\pi \\
(\mathrm{erg} / \mathrm{col})\end{array}$ \\
\hline $\begin{array}{l}\text { BL asphalt } \\
\text { emulsion }\end{array}$ & 34.8 & - & - & - \\
\hline 0 & - & - & 83.1 & 82.7 \\
\hline 1 & 97.8 & 63.8 & 103.0 & 57.2 \\
\hline 2 & 81.1 & 85.2 & 102.2 & 58.2 \\
\hline 3 & 83.0 & 82.8 & 103.5 & 56.6 \\
\hline $3(2 x$ nixed) & 93.2 & 69.7 & 100.1 & 60.9 \\
\hline 4 & 69.6 & 99.5 & 98.4 & 63.0 \\
\hline 5 & 67.6 & 101.9 & 98.6 & 62.8 \\
\hline 6 & 100.0 & 61.0 & 102.2 & 58.2 \\
\hline 7 & 90.0 & 73.8 & 84.7 & 80.6 \\
\hline 8 & 90.0 & 73.8 & 87.0 & 77.7 \\
\hline 9 & 106.0 & 53.5 & 75.6 & 53.5 \\
\hline 10 & 89.0 & 75.1 & 89.0 & 75.1 \\
\hline 11 & 98.0 & 63.5 & 120.5 & 36.3 \\
\hline 12 & 90.7 & 72.9 & 91.2 & 72.3 \\
\hline $13(1 x$ mixed $)$ & 85.0 & 80.2 & 84.5 & 80.9 \\
\hline
\end{tabular}

Table 6 for various types of treated surfaces. Asphalt concrete surface finished with mixture of BL asphalt emulsion and cement (weight ratio 1 : 1) was used for untreated surface for this measurement.

\section{(6) Critical surface tension of asphalt}

For untreated surface described above, Zisman plot was done as shown in Fig.9. Critical surface tension $\gamma_{c}$ was obtained as 33.0 dyne $/ \mathrm{cm}$.

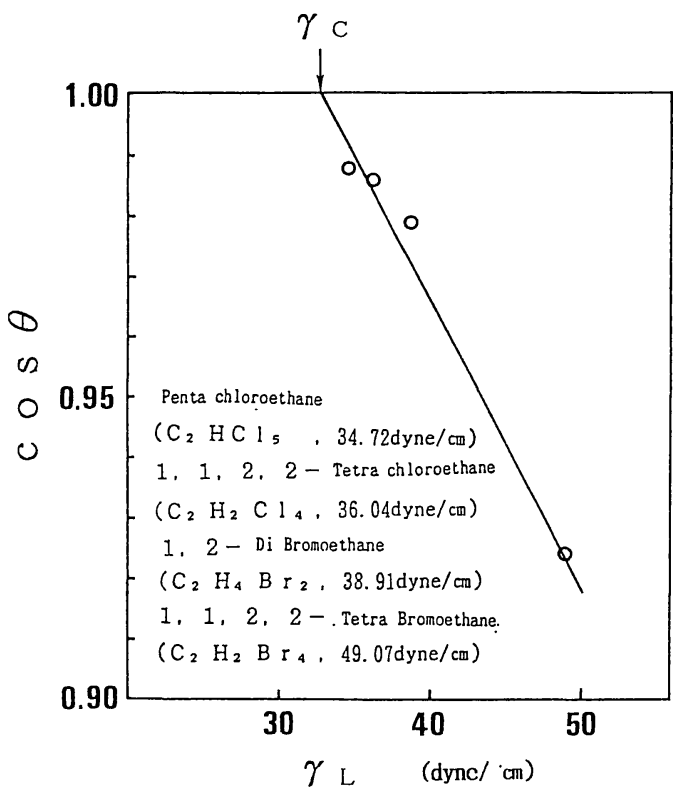

Fig.9 Zisman Plot for Critical Surface Tension $\left(\gamma_{c}\right)$

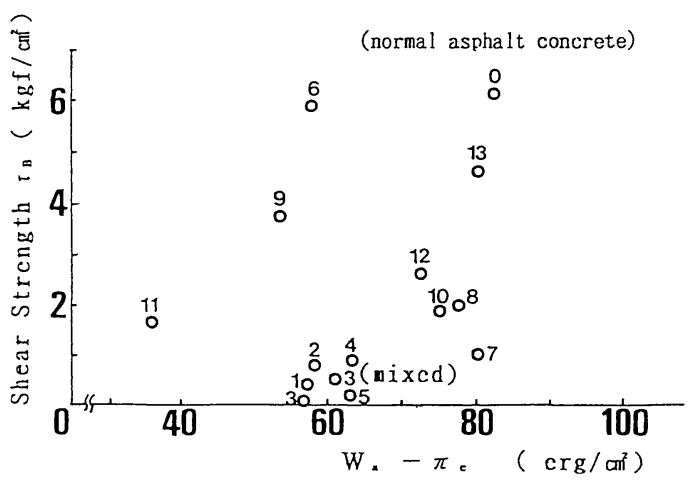

Fig.10 Relation between $W_{a}-\pi_{c}$ and $\tau_{B}$ (water)

(7) Relation between adhesional energy of water and shear debonding strength of ice-asphalt concrete interface

Relation between the data shown in 3.(3) and the data shown in 3.(5) can be plotted as Fig.10. Relation between debonding strength and adhesional energy $W_{a}-\pi_{c}$ is not so clear. But in reference to icing force, rather linear relation is reported by Shimada et. al. ${ }^{1)}$.

(8) Effect of roughness of shear debonding strength

For repellent coated surface (No.3) shear debonding strength is linearly decreased with decreasing roughness (Fig.11), but for untreated asphalt concrete shear debonding strength is not influenced by roughness of pavement.

(9) Effect of roughness on debonding energy by impact tension 


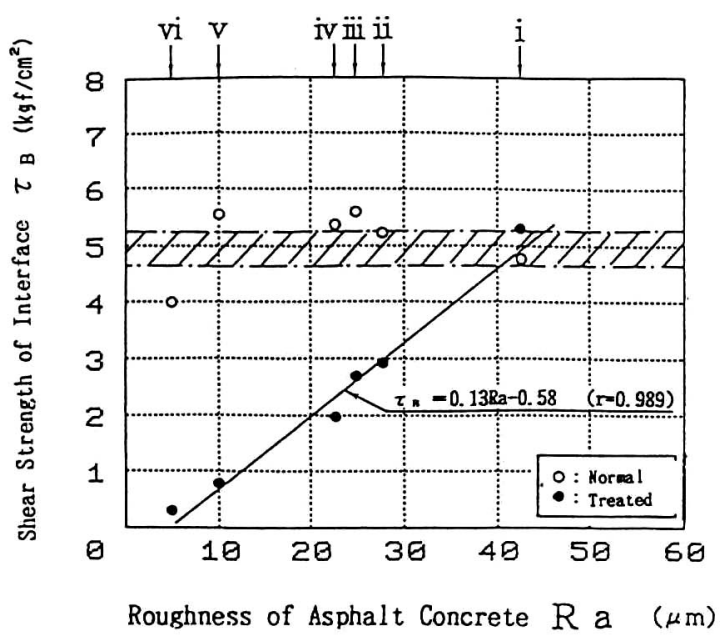

Fig.11 Relation between Roughness of Asphalt Concrete and Shear Strength of Interface

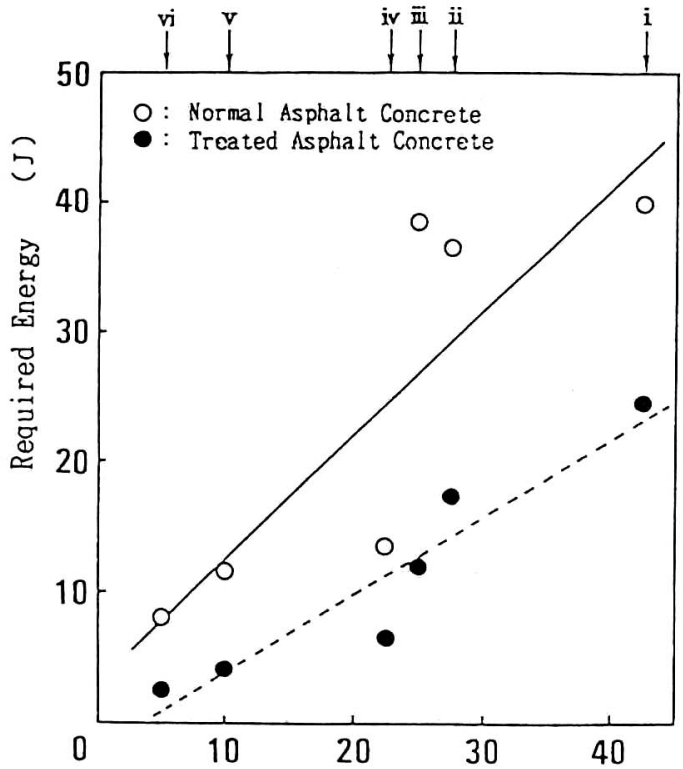

Roughness of Asphalt Concrete $\mathrm{Ra}(\mu \mathrm{m})$

Fig.12 Relation between Required Energy and Roughness of Asphalt Concrete (Drop Height $20 \mathrm{~cm}$ )

For the case of debonding by impact tension, roughness of asphalt concrete influences energy requirement for both treated and untreated surface (Fig.12). This means that, for asphalt concrete, tension type of debonding is more effective than shear type of debonding. Stiking contrast between Fig.11 and 12 could be attributed to the difference in mechanism of interfacial debonding.

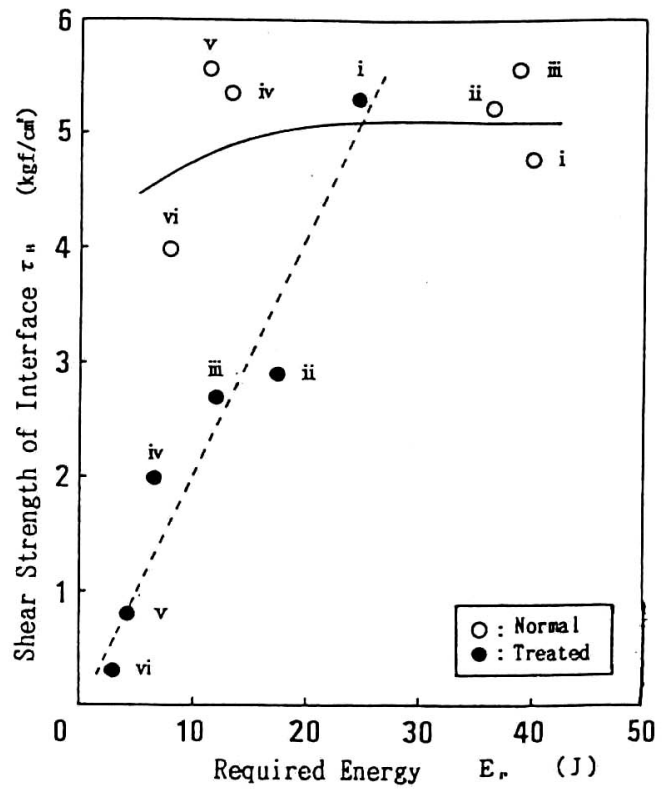

Fig.13 Relation between Single Plane Shear Strength and Impact Tensile Strength of Ice-Asphalt Concrete Interface

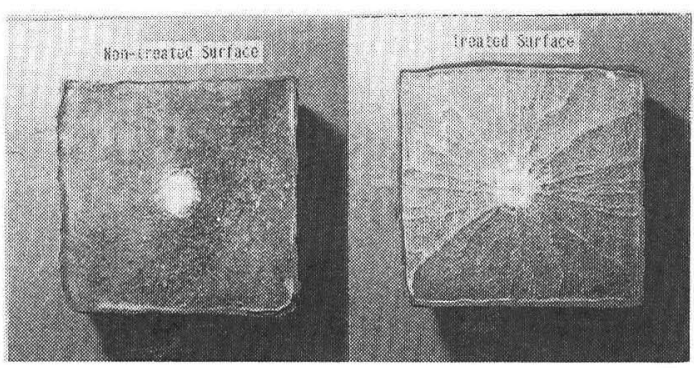

Photo 5 Surface after One Blow

(10) Relation between shear debonding strength and energy requirement by impact tension

For repellent coated surface, either of these two indices could be used to evaluate debonding resistance of ice-asphalt concrete interface. But for asphalt concrete surface, impact tension test is more effective than shear debonding test (Fig.13).

(11) Visual observation of ice debonding

By single impact blow of Shmidt Hammer, no crack or debonding was observed for $5 \mathrm{~mm}$ ice on asphalt concrete $(10 \times 10 \mathrm{~cm})$, but many radial cracks were observed in ice for the case of repellent coated (No.3) surface (Photo 5). After five blows all ice bonded to repellent coated surface was gone, while most part of ice remained on non-coated surface without cracking (Photo 6). 


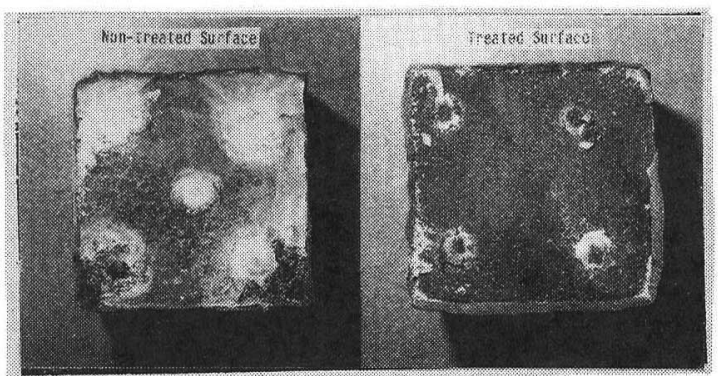

Photo 6 Surface after Five Blows
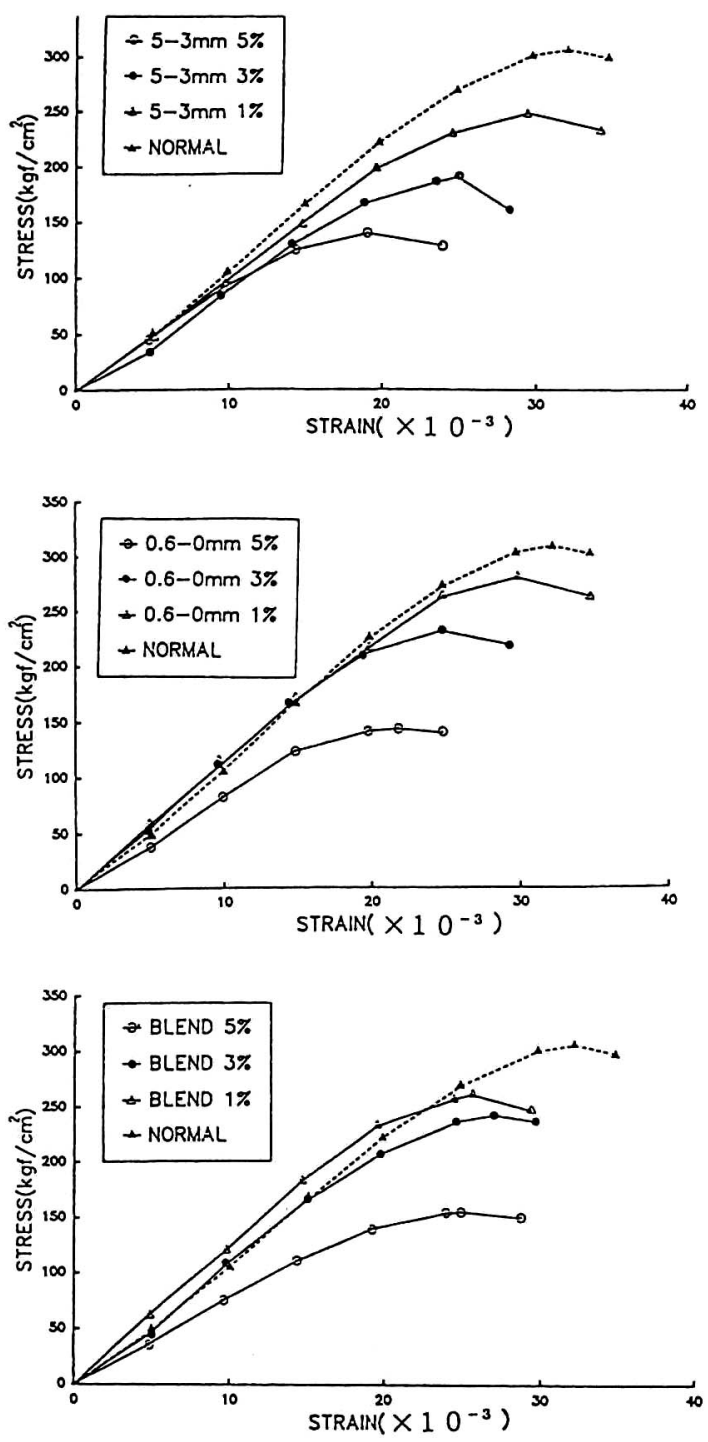

Fig.14 Stress-strain Curve of Asphalt Concrete Containing Different Amount of Rubber Particles $\left(-15^{\circ} \mathrm{C}\right)$
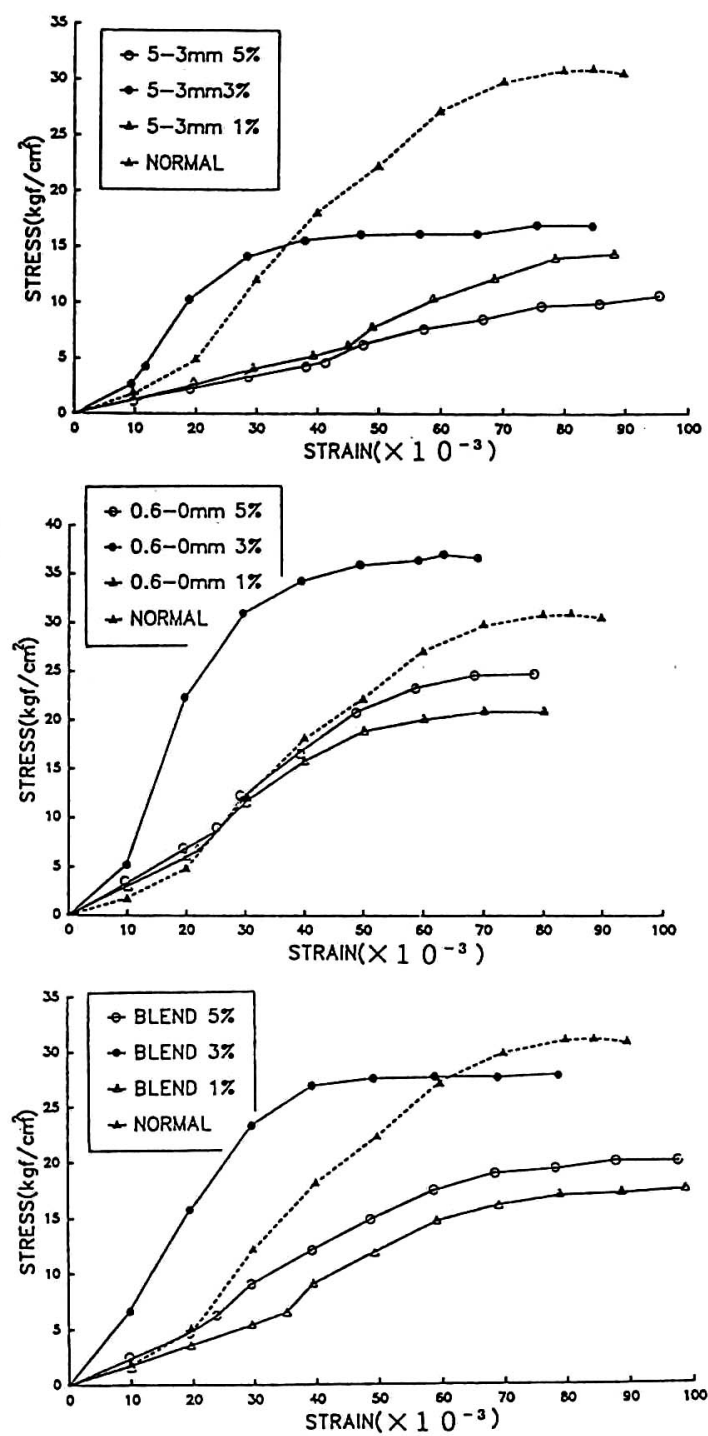

Fig.15 Stress-strain Curve of Asphalt Concrete Containing Different Amount of Rubber Particles $\left(20^{\circ} \mathrm{C}\right)$

\section{TEST RESULTS OF SERIES 2}

(1) Stress-strain curve of rubber mixed asphalt $\left(-15^{\circ} \mathrm{C}\right)$

At temperature $-15^{\circ} \mathrm{C}$, addition of rubber particles always reduces the maximum stress and stiffness of asphalt concrete (Fig.14). Effect of grain size distribution is clearly recognized. For 5 $3 \mathrm{~mm}$ rubber aggregate, the maximum reduction in stiffness was obtained.

(2) Stress-strain curve of rubber mixed asphalt $\left(20^{\circ} \mathrm{C}\right)$

At temperature $20^{\circ} \mathrm{C}$, initial stiffness is increased only for $3 \%$ of rubber content (Fig.15). 


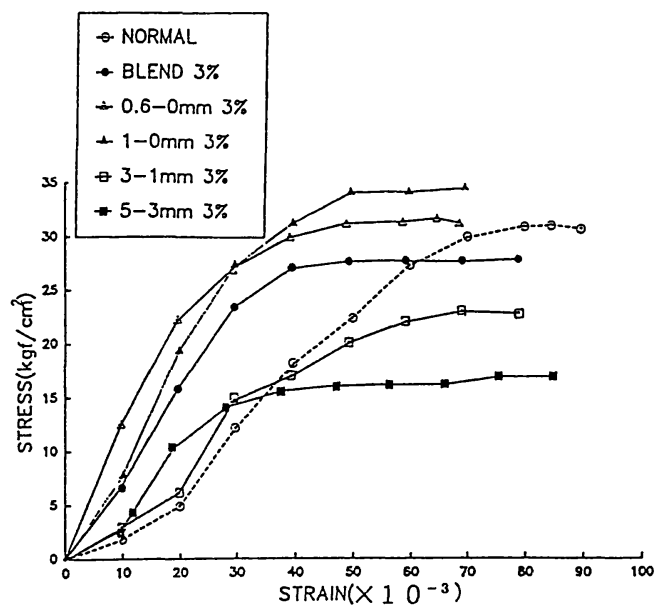

Fig.16 Stress-strain Curve (Effect of Size Rubber Particles, $20^{\circ} \mathrm{C}$ )

This increase is more pronounced for smaller size of rubber particle. The maximum stress is also increased with increase in stiffness (Fig.16).

\section{(3) Ice failure by plunger load}

For asphalt concrete containing different amount of rubber particles, failure load of ice bonded to the surface of asphalt concrete by static local compression of plunger is shown in Table 7.

Maximum load of ice failure can be reduced by $30 \%$ by mixing $3 \%$ of rubber $5 \sim 3 \mathrm{~mm}$ in particle size.

\section{CONCLUSIONS}

(1) Reducing surface energy and/or increasing deformability of asphalt concrete is an effective way to decrease interfacial bonding resistance between ice and asphalt concrete. In this regard, use of water repellent agent or replacement of aggregate with rubber particles is a promissing method to facilitate debonding of ice and asphalt concrete pavement.

(2) For repellent coated surface shear debonding strength is linearly related to the energy required for debonding by dynamic tension. But for uncoated surface, no direct relation was found between these two types of strength.

(3) For uncoated surface, shear debonding strength is not influenced by roughness of pavement. But for coated surface, shear debonding strength is linearly decreased with decrease in roughness of pavement.

(4) The energy required for tensile debonding is linearly related to the roughness of pavement both for repellent-coated and non-coated surface.
Table 7 Local Plunger Load (kgf) of Ice Failure

\begin{tabular}{|c|c|c|c|c|}
\hline $\begin{array}{l}\text { Grain } \\
\text { Rubber size } \\
\text { content }(x)\end{array}$ & $5 \sim 3 \mathrm{~cm}$ & $0.6 \sim 0 \mathrm{~mm}$ & Blended & $\begin{array}{l}\text { Normal } \\
\text { Asphalt } \\
\text { Concrete }\end{array}$ \\
\hline 5 & $\begin{array}{c}1690 \\
(0.72)\end{array}$ & $\begin{array}{c}1728 \\
(0.74)\end{array}$ & $\begin{array}{c}2080 \\
(0.89)\end{array}$ & \multirow{3}{*}{$\begin{array}{l}2347 \\
(1.0)\end{array}$} \\
\hline 3 & $\begin{array}{c}1695 \\
(0.72)\end{array}$ & $\begin{array}{c}1898 \\
(0.81)\end{array}$ & $\begin{array}{c}2157 \\
(0.92)\end{array}$ & \\
\hline 1 & $\begin{array}{c}2365 \\
(1.01)\end{array}$ & $\begin{array}{c}2060 \\
(0.88)\end{array}$ & $\begin{array}{c}2278 \\
(0.97)\end{array}$ & \\
\hline
\end{tabular}

(5) When bonding between ice and asphalt concrete pavement is weakened either by a surface chemical or mechanical method, radial cracks starting from the spot where dynamic or static load was applied, were formed in ice by local compression and ice pieces were easily taken off.

(6) Shear debonding strength can be related to bonding energy between water and asphalt concrete surface at 20 degree centigrade which is experimentally determined by contact angle measurement.

\section{ACKNOWLEDGEMENT}

The authors wish to convey their gratitude to Professor Kazuo Fujino of Hokkaido University for his advices to prepare samples.

Sincere gratitudes are expressed to Messrs Yoshiharu Yamashita and Hiroshi Mita working with Taisei Road Co., Ltd for their collaboration. The authors are grateful to Assistant Professor Asuo Yonekura and Assistant Shingo Miyazawa. Thanks are also extended to Messrs Ichiro Ohtsu, Hiroyuki Harada and Masahide Ohtani for their efforts spent for the experiments.

\section{REFERENCE}

1) Shimoda, T. et al : Antifreezing Agent "Defro," Paint Investigation (in Japanese) No.112, 1986

2) Jhon, C. Cook : Icephobic Coatings for Highway Pavements, Snow Removal and Ice Control Research, special report 185, National Academy of Sciences 1979.

3) Ashworth, T. Tollefsen B. and Weyland, J.A. : Adhesion of Ice to Concrete Surfaces-Preliminary Results, ibid.

4) Katsutoshi Yano and Daisuke Kuroiwa : Adhesive Strength of Contaminated Ice, ibid.

5) Paul, R. and David, J. Halehim, : Electrical Properties of Ice-Solid Interfaces, ibid.

6) Robert R. Blackburn and Andrew D. St. John : Physical Alternatives to Chemicals for Highway Deicing, ibid.

(Received August 12, 1991) 


\section{アスファルト一氷界面の付着低減法}

田澤栄一・溝上裕二・览島武男

水とアスファルト舗装の付着機構を明らかにし, 新しい付着抵抗の低減法を開発する ために，一連の実験的検討を行った. 界面の付着抵抗を 3 つの方法で測定した. 表面工 ネルギー, 表面粗さ,アスファルトの剛性を主な変数とした。表面エネルギーは溌水剤 の使用により変化させ, アスファルトの剛性はゴム粒子の混入により変化させた. 3 変 数の関係を検討し以下の結論が得られた. 表面エネルギーの低隇およびアスファルトの 変形性能の向上は氷とアスファルトの付着を低滅する有効な方法である. この点で, 溌 水剤の使用およびゴム粒子の骨材への置き換えは, 舗装面への水付着低滅法として期待 できる. 